\title{
Pseudomonas deceptionensis sp. nov., a psychrotolerant bacterium from the Antarctic
}

\author{
Ornella Carrión, David Miñana-Galbis, $M^{a}$ Jesús Montes \\ and Elena Mercadé
}

Correspondence

Elena Mercadé

mmercade@ub.edu

\author{
Laboratori de Microbiologia, Facultat de Farmacia, Universitat de Barcelona, Av. Joan XXIII s/n, \\ 08028 Barcelona, Spain
}

\begin{abstract}
During the taxonomic investigation of cold-adapted bacteria from samples collected in the Antarctic area of the South Shetland Islands, one Gram-reaction-negative, psychrotolerant, aerobic bacterium, designated strain $\mathrm{M}^{\top}{ }^{\top}$, was isolated from marine sediment collected on Deception Island. The organism was rod-shaped, catalase- and oxidase-positive and motile by means of a polar flagellum. This psychrotolerant strain grew at temperatures ranging from $-4{ }^{\circ} \mathrm{C}$ to $34{ }^{\circ} \mathrm{C}$. Phylogenetic studies based on $16 \mathrm{~S}$ rRNA gene sequences confirmed that Antarctic isolate $\mathrm{M} 1^{\top}$ was a member of the genus Pseudomonas and was located in the Pseudomonas fragi cluster. 16S rRNA gene sequence similarity values were $>98 \%$ between 13 type strains belonging to the Pseudomonas fluorescens lineage. However, phylogenetic analysis of $r p o D$ gene sequences showed that strain $\mathrm{M} 1^{\top}$ exhibited high sequence similarity only with respect to Pseudomonas psycrophila (97.42\%) and P. fragi (96.40\%) and DNA-DNA hybridization experiments between the Antarctic isolate $\mathrm{M}^{\top}{ }^{\top}$ and the type strains of these two closely related species revealed relatedness values of 58 and $57 \%$, respectively. Several phenotypic characteristics, together with the results of polar lipid and cellular fatty acid analyses, were used to differentiate strain $\mathrm{M}^{\top}{ }^{\top}$ from related pseudomonads. Based on the evidence of this polyphasic taxonomic study, strain $\mathrm{M} 1^{\top}$ represents a novel species, for which the name Pseudomonas deceptionensis sp. nov. is proposed. The type strain is $\mathrm{M}^{\top}{ }^{\top}\left(=\mathrm{LMG} 25555^{\top}=\mathrm{CECT} 7677^{\top}\right)$.
\end{abstract}

In recent years, attention has been increasingly devoted to cold-adapted micro-organisms and their enzymes (Antranikian et al., 2005). Antarctica has become a great source of novel psychrophilic and psychrotolerant strains, some of them belonging to the genus Pseudomonas (Kriss et al., 1976; Shivaji et al., 1989; Ma et al., 2006; Maugeri et al., 1996; Bruni et al., 1999; Reddy et al., 2004). During a taxonomic investigation of cold-adapted bacteria, soil, water and sediment samples were collected on Deception Island in the Antarctic area of the South Shetland Islands. From these samples, eight strains that were able to grow at 0-30 ${ }^{\circ} \mathrm{C}$ were isolated. Two of these strains were classified as Pseudomonas guineae in previous studies (Bozal et al., 2007), two were classified as a novel species of the genus Marinobacter, Marinobacter guineae (Montes et al. 2008), and another two strains were classified as Shewanella vesiculosa (Bozal et al. 2009). Another isolate, designated

Abbreviations: DPG, diphosphatidylglycerol; MLSA, multilocus sequence analysis; PE, phosphatidylethanolamine; PG, phosphatidylglycerol.

The GenBank/EMBL/DDBJ accession numbers for the 16S rRNA and $r p o D$ gene sequences of strain $M 1^{\top}$ are GU936597 and GU936596, respectively.

Four supplementary figures and two supplementary tables are available with the online version of this paper. strain $\mathrm{M}^{\mathrm{T}}$, was able to grow at -4 to $34{ }^{\circ} \mathrm{C}$ and was characterized further in this study. The taxonomic status of strain $\mathrm{M}^{\mathrm{T}}$ was investigated by using a combination of phenotypic characterization, 16S rRNA and rpoD gene sequencing, DNA G + C content determination, DNA-DNA hybridization experiments and cellular fatty acid analysis. The data obtained showed that strain $\mathrm{M1}^{\mathrm{T}}$ represented a novel species of the genus Pseudomonas, for which the name Pseudomonas deceptionensis sp. nov. is proposed.

Strain $\mathrm{M1}^{\mathrm{T}}$ was isolated from a marine sediment sample collected from Deception Island (South Shetland Islands, Antarctica). Sample aliquots were removed with a platinum loop and diluted in a saline solution $(\mathrm{pH} \mathrm{7})$ containing the following salts $\left(\mathrm{g} \mathrm{l}^{-1}\right)$ : $\mathrm{NaCl}(0.56), \mathrm{KCl}$ (0.027), $\mathrm{CaCl}_{2}$ (0.03) and $\mathrm{NaHCO}_{3}(0.01)$. Tryptic soy agar (TSA) plates (Oxoid) were inoculated with loopfuls of several sample dilutions by using the streak-plate method to obtain isolated colonies. The plates were incubated for 4 days at $15{ }^{\circ} \mathrm{C}$. Isolates were maintained aerobically on TSA slopes at $4{ }^{\circ} \mathrm{C}$ and also at $-80{ }^{\circ} \mathrm{C}$ in cryo-beads (AES Laboratoire).

Phenotypic characteristics of strain $\mathrm{M1}^{\mathrm{T}}$ and its most closely related species, Pseudomonas psychrophila DSM $17535^{\mathrm{T}}$, Pseudomonas fragi DSM $3456^{\mathrm{T}}$, Pseudomonas 
lundensis DSM $6252^{\mathrm{T}}$ and Pseudomonas taetrolens DSM $21104^{\mathrm{T}}$, were investigated simultaneously. The morphology of cells grown on TSA at $15{ }^{\circ} \mathrm{C}$ was determined by means of negative staining and transmission electron microscopy (JEOL 1010) of ultrathin sections after freeze fixation and freeze-substitution (Nevot et al., 2006). Cell motility was determined by phase-contrast microscopy. Oxidase, catalase and urease activities, nitrate reduction and hydrolysis of casein, lecithin, gelatin, DNA, starch and Tween 80 were determined according to Barrow \& Feltham (1993). The presence of fluorescent pigments was tested under UV light after 8 days on King's B medium (King et al., 1954). Acid production from carbohydrates, enzyme production and additional characteristics were determined by using API 50 $\mathrm{CH}$, API ZYM and API 20 NE strips (bioMérieux) and Biolog GENIII MicroPlates (Biolog) according to the instructions of the manufacturer. Tolerance of $\mathrm{NaCl}$ was determined by growth on nutrient agar (Cultimed) containing $0-7 \%(\mathrm{w} / \mathrm{v}) \mathrm{NaCl}$ after 20 days of incubation at $20{ }^{\circ} \mathrm{C}$. Growth at -4 to $42{ }^{\circ} \mathrm{C}$ was determined on TSA after 14 days of incubation and growth at $\mathrm{pH} 3.5-11.0$ (increments of $0.5 \mathrm{pH}$ units) was determined in tryptic soy broth (TSB; Difco) after 10 days of incubation at $20{ }^{\circ} \mathrm{C}$. Anaerobic growth was determined on TSB plus $1.5 \%$ agar and on Marine agar (MA; Difco) after incubation in an anaerobic chamber at $20{ }^{\circ} \mathrm{C}$ for 14 days.

Cells of strain $\mathrm{M1}^{\mathrm{T}}$ were Gram-reaction-negative, rodshaped $(0.8 \times 1.5-2.0 \mu \mathrm{m})$ and motile by means of a single polar flagellum (Supplementary Fig. S1, available in IJSEM Online). Colonies of the novel isolate grown on TSA at $20{ }^{\circ} \mathrm{C}$ for $72 \mathrm{~h}$ were white, round, mucous, slightly convex and $1.5-2 \mathrm{~mm}$ in diameter and did not produce fluorescent pigments on King's B medium. The isolate grew at temperatures ranging from -4 to $34{ }^{\circ} \mathrm{C}$ and tolerated $\mathrm{NaCl}$ concentrations of up to $6 \%(\mathrm{w} / \mathrm{v})$ on nutrient agar. The novel isolate was negative for the hydrolysis of lecithin, casein, starch, Tween 80 and DNA. Other phenotypic characteristics of strain $\mathrm{Ml}^{\mathrm{T}}$ and its closest phylogenetic relatives are shown in Table 1 . These phenotypic studies showed that the novel isolate displayed characteristics consistent with those of members of the genus Pseudomonas and could be clearly differentiated from the its most closely related species.

Cellular fatty acids from strain $\mathrm{M1}^{\mathrm{T}}$ and its closest phylogenetic neighbours were prepared from $40 \mathrm{mg}$ wet cell material harvested from a TSB agar $\left(30 \mathrm{~g} \mathrm{TSB}^{-1}, 15 \mathrm{~g}\right.$ agar $\mathrm{l}^{-1}$ ) culture after $24 \mathrm{~h}$ of incubation at $28{ }^{\circ} \mathrm{C}$. Whole-cell fatty acids were determined as described previously by Bozal et al. (2002). The mean fatty acid composition of strain $\mathrm{Ml}^{\mathrm{T}}$, together with those of the type strains of the closest phylogenetic neighbours, are shown in Supplementary Table S1. The most abundant fatty acids were $\mathrm{C}_{16: 0}$ (34.9\%), summed feature 3 (iso- $\mathrm{C}_{15: 0} 2-\mathrm{OH}$ and/or $\mathrm{C}_{16: 1}$ $\omega 7 c, 21.5 \%)$ and $\mathrm{C}_{17: 0}$ cyclo $(16.1 \%)$. This profile was similar to that of other phylogenetically related strains except for that of $P$. lundensis DSM $6252^{\mathrm{T}}$, which showed a remarkably high proportion of hydroxy fatty acids.
Polar lipids were analysed as described by Tindall (1990). The polar lipid profile of strain $\mathrm{Mi}^{\mathrm{T}}$ consisted of phosphatidylethanolamine (PE), diphosphatidylglycerol (DPG), and phosphatidylglycerol (PG) as the major components, moderate amounts of unknown aminolipids (AL1-3), unknown phospholipids (PL1, PL2) and unknown polar lipids (L3, L7, L9), and minor to trace amounts of unknown polar lipids (L1-2, L4-6, L8, L10-13) (Supplementary Fig. S4). Strain $\mathrm{M}^{\mathrm{T}}$ and its closest phylogenetic relative Pseudomonas psychrophila DSM $17535^{\mathrm{T}}$ exhibited almost identical polar lipid profiles.

Genomic DNA of strain $\mathrm{M1}^{\mathrm{T}}$ was prepared according to the protocol of Niemann et al. (1997). A $1452 \mathrm{nt}$ portion of the 16S rRNA gene was sequenced as described previously by Bozal et al. (2002). PCR amplification and sequencing of the $r p o D$ gene of strain $\mathrm{Ml}^{\mathrm{T}}$ were carried out as described previously (Yamamoto \& Harayama, 1998). Multiple sequence alignments, distance matrix calculations and phylogenetic analysis of $16 \mathrm{~S}$ rRNA and $r p o D$ gene sequences from strain $M 1^{\mathrm{T}}$ and related species, taken from GenBank, were performed using MEGA version 4.0 (Tamura et al., 2007). Phylogenetic trees were reconstructed using the maximum-parsimony and neighbour-joining methods and their topological robustness was evaluated by bootstrap analysis based on 1000 replicates. For DNA-DNA hybridization experiments and the determination of $\mathrm{G}+\mathrm{C}$ content, total DNA was prepared according to the procedure of Wilson (1987) with modifications. The $\mathrm{G}+\mathrm{C}$ content was determined by using the HPLC technique as described by Mesbah et al. (1989). DNA-DNA hybridizations were performed at $47^{\circ} \mathrm{C}$ according to the method described by Ezaki et al. (1989) with the modifications of Goris et al. (1998) and Cleenwerck et al. (2002).

Phylogenetic analyses based on 16S rRNA gene sequences confirmed that strain $\mathrm{M1}^{\mathrm{T}}$ was a member of the genus Pseudomonas and was located in the $P$. fragi cluster with a bootstrap value of $99 \%$ (Supplementary Fig. S2). 16S rRNA gene sequence similarity values greater than $98 \%$, the mean value considered to be the threshold for the identification of strains as the same species within a genus (Yarza et al., 2008), were found with 13 type strains belonging to the $P$. fluorescens lineage (Supplementary Table S2). Due to the low resolution of $16 \mathrm{~S}$ rRNA gene sequences at the intrageneric level, the rpoD gene, the most discriminating housekeeping gene described to date in the genus Pseudomonas (Mulet et al., 2010), was selected for analysis. The comparison of this gene as individual datasets or as combined concatenated sequences provided a higher resolution analysis than 16S rRNA gene sequences alone and also complemented the results of DNA-DNA relatedness studies (Tindall et al., 2010). Compressed and expanded rpoD phylogenetic trees, reconstructed using the neighbour-joining method with the Jukes-Cantor model, are shown in Fig. 1 and Supplementary Figure S3, respectively. As shown in Supplementary Table S2, only $P$. psycrophila (97.42\%) and P. fragi (96.40\%) exhibited high rpoD gene sequence similarities with respect to strain $\mathrm{M}^{\mathrm{T}}$, 
Table 1. Characteristics of strain $M 1^{\top}$ and its closest phylogenetic neighbours

Strains: $1, \mathrm{M1}^{\mathrm{T}} ; 2$, P. psychrophila DSM $17535^{\mathrm{T}} ; 3$, P. fragi DSM $3456^{\mathrm{T}} ; 4$, P. lundensis DSM $6252^{\mathrm{T}} ; 5$, P. taetrolens DSM $21104^{\mathrm{T}}$. All strains are Gram-reaction-negative rods that are motile by means of a polar flagellum and positive for catalase and oxidase activities. All data are from this study unless indicated otherwise. +, Positive; -, negative; w, weakly positive; ND, not determined.

\begin{tabular}{|c|c|c|c|c|c|}
\hline Characteristic & 1 & 2 & 3 & 4 & 5 \\
\hline Cell length $(\mu \mathrm{m})$ & $1.5-2.0$ & $2.0-2.7$ & $1.3-2.6$ & $1.2-1.8$ & $1.5-3.4$ \\
\hline Cell diameter $(\mu \mathrm{m})$ & 0.8 & 0.7 & 0.8 & 0.7 & 0.6 \\
\hline $\mathrm{pH} 4.5$ & - & - & + & - & - \\
\hline$-4{ }^{\circ} \mathrm{C}$ & + & + & + & $\mathrm{w}$ & + \\
\hline $36{ }^{\circ} \mathrm{C}$ & - & - & - & + & - \\
\hline \multicolumn{6}{|l|}{ Enzyme activities: } \\
\hline Gelatinase & - & - & + & + & - \\
\hline Esterase lipase C8 & - & $\mathrm{w}$ & $\mathrm{w}$ & - & + \\
\hline Trypsin, $\alpha$-chymotrypsin & - & - & + & - & - \\
\hline Valine arylamidase & - & $\mathrm{w}$ & + & $\mathrm{w}$ & $\mathrm{w}$ \\
\hline \multicolumn{6}{|l|}{ Acid production from (API $50 \mathrm{CH}$ ): } \\
\hline Lactose & + & + & - & - & $\mathrm{w}$ \\
\hline Sucrose, trehalose & + & + & + & - & - \\
\hline Raffinose & + & + & - & - & - \\
\hline Gentiobiose & + & + & $\mathrm{w}$ & - & + \\
\hline L-Fucose & + & + & + & - & + \\
\hline \multicolumn{6}{|l|}{ Oxidation of (Biolog GENIII): } \\
\hline D-Mannose & - & + & + & - & + \\
\hline D-Galacturonic acid & - & + & - & - & + \\
\hline Glycerol, L-glutamic acid, L-histidine & - & + & - & + & + \\
\hline L-Pyroglutamic acid & - & + & - & + & - \\
\hline Quinic acid & + & - & + & - & + \\
\hline$r p o D$ sequence similarity to strain $\mathrm{M}^{\mathrm{T}}(\%)$ & 100 & 97.4 & 96.4 & 90.4 & 93.5 \\
\hline DNA-DNA hybridization with strain $\mathrm{M1}^{\mathrm{T}}(\%)$ & 100 & 58 & 57 & $\mathrm{ND}$ & $\mathrm{ND}$ \\
\hline
\end{tabular}

${ }^{\star}$ Data from Yumoto et al. (2001).

$\dagger$ Data from Molin et al. (1986).

\$Data from De Vos et al. (1989).

since a $97 \%$ sequence similarity in MLSA analysis has been proposed as the minimal value between strains of the same species (Mulet et al., 2010). To further verify the taxonomic position of the Antarctic isolate $\mathrm{Ml}^{\mathrm{T}}$, DNA-DNA hybridizations were performed with $P$. psychrophila LMG $24276^{\mathrm{T}}$ and P. fragi LMG $2191^{\mathrm{T}}$. The resultant low DNA-DNA reassociation values $(58 \%$ and $57 \%$ with the type strains of P. psychrophila and P. fragi, respectively), along with the results of $16 \mathrm{~S}$ rRNA and $r p o D$ gene sequence analyses, showed that strain $\mathrm{Ml}^{\mathrm{T}}$ occupied a distinct position in the genus Pseudomonas (Wayne et al., 1987). The DNA G +C content of strain $\mathrm{Ml}^{\mathrm{T}}$ was $58.3 \mathrm{~mol} \%$, which lies within the range described for members of genus Pseudomonas.

The morphological, physiological, chemotaxonomic and phylogenetic data obtained in this study showed that strain $\mathrm{M1}^{\mathrm{T}}$ belongs to the genus Pseudomonas. DNA-DNA hybridization analyses clearly distinguished strain $\mathrm{M1}^{\mathrm{T}}$ from its closest relatives, P. psychrophila LMG $24276^{\mathrm{T}}$ and P. fragi LMG $2191^{\mathrm{T}}$. On the basis of the data from this 


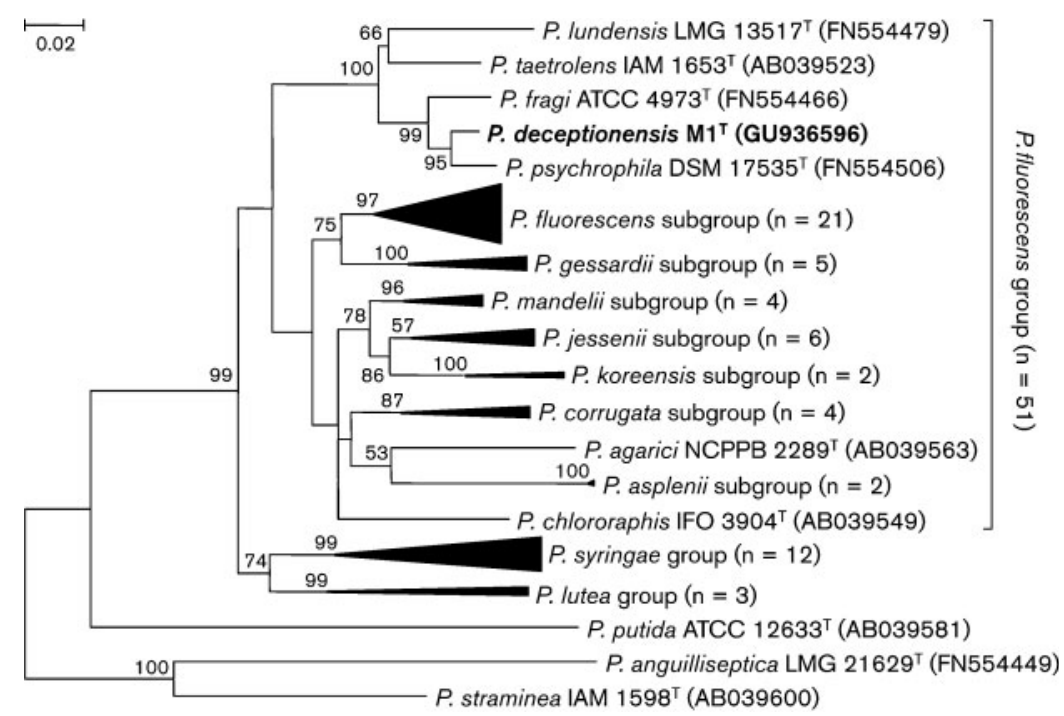

Fig. 1. Compressed neighbour-joining phylogenetic tree based on $r p o D$ sequences of strain $\mathrm{M} 1^{\top}$ and type strains of closely related species of the genus Pseudomonas. Number of strains ( $n$ ) in collapsed subgroups and GenBank accession numbers for individual type strains are indicated in parentheses. Bar, 0.02 substitutions per nucleotide position. Bootstrap values $>50 \%$ (based on 1000 replicates) are shown at branch points. polyphasic study, $\mathrm{M1}^{\mathrm{T}}$ represents a novel species of the genus Pseudomonas, for which the name Pseudomonas deceptionensis sp. nov. is proposed.

\section{Description of Pseudomonas deceptionensis sp. nov.}

Pseudomonas deceptionensis (de.cep.tio.nen'sis. N.L. fem. adj. deceptionensis pertaining to Deception Island, Antarctic Sea).

Cells are rod-shaped $(0.8 \times 1.5-2.0 \mu \mathrm{m})$, Gram-reactionnegative, oxidase-positive, non-spore-forming and motile by means of a single polar flagella. Does not produce fluorescent pigments on King's B medium. After $72 \mathrm{~h}$ of incubation at $20{ }^{\circ} \mathrm{C}$ on TSA, colonies are $1.5-2.0 \mathrm{~mm}$ in diameter, white, round, mucous and slightly convex. Growth occurs at -4 to $34{ }^{\circ} \mathrm{C}$ and at $\mathrm{pH} 5-10 . \mathrm{NaCl}$ is tolerated at concentrations up to $6 \%(\mathrm{w} / \mathrm{v})$. Growth on MA is very poor under anaerobic conditions. Positive for catalase, leucine arylamidase, acid phosphatase and naphthol-AS-BI-phosphohydrolase activities but negative for alkaline phosphatase, esterase (C4), esterase lipase (C8), lipase (C14), valine arylamidase, cystine arylamidase, trypsin, $\alpha$-chymotrypsin, $\alpha$ - and $\beta$-galactosidase, $\beta$-glucuronidase, $\alpha$ - and $\beta$-glucosidase, $N$-acetyl- $\beta$-glucosaminidase, $\alpha$-mannosidase and $\alpha$-fucosidase activities. Negative for hydrolysis of aesculin, Tween 80 , gelatin, casein, starch and lecithin but positive for hydrolysis of urea. Negative for indole and hydrogen sulfide production and nitrate reduction. In API $50 \mathrm{CH}$ tests, acid is produced from D- and L-arabinose, Dfructose, cellobiose, D- and L-fucose, D-galactose, glycerol, Dglucose, inositol, lactose, D-mannitol, D-mannose, maltose, melibiose, raffinose, gentiobiose, D-ribose, sucrose, trehalose and D-xylose. In Biolog GENIII MicroPlates, positive for oxidation of D-galactose, D-glucuronic acid, D-fucose, glucuronamide, acetoacetic acid, L-fucose and quinic acid; also positive for growth in the presence of $1 \%$ sodium lactate, troleandomycin, lincomycin, vancomycin, aztreonam, fusic acid, rifampicin SV, tetrazolium violet, D-serine, niaproof 4 and potassium telurite. Fatty acid profile contains $\mathrm{C}_{16: 0}$ $(34.9 \%)$, summed feature 3 (iso- $\mathrm{C}_{15: 0} 2-\mathrm{OH}$ and/or $\mathrm{C}_{16: 1}$; $21.5 \%$ ) and $\mathrm{C}_{17: 0}$ cyclo (16.1\%), as the major fatty acids with smaller proportions of $\mathrm{C}_{18: 1} \omega 7 c(4.9 \%), \mathrm{C}_{10: 0} 3-\mathrm{OH}(5.4 \%)$, $\mathrm{C}_{12: 0} 2-\mathrm{OH}(5.8 \%), \mathrm{C}_{12: 0} 3-\mathrm{OH}(5.6 \%), \mathrm{C}_{12: 0}(3.6 \%)$ and $\mathrm{C}_{14: 0}(1.7 \%)$. The polar lipid profile consists of the major compounds PE, DPG and PG; moderate amounts of three unknown aminolipids, two unknown phospholipids and three unknown polar lipids; and minor to trace amounts of 10 unknown polar lipids.

The type strain, $\mathrm{M1}^{\mathrm{T}}\left(=\mathrm{LMG} 25555^{\mathrm{T}}=\mathrm{CECT} 7677^{\mathrm{T}}\right)$, was isolated from a marine sediment sample collected from Deception Island, South Shetland Islands, Antarctica. The DNA $\mathrm{G}+\mathrm{C}$ content of the type strain is $58.3 \mathrm{~mol} \%$.

\section{Acknowledgements}

We thank Dr E. García-Valdés for her preliminary rpoD sequence analysis. We acknowledge the BCCM/LMG Identification Service (BCCM/LMG Bacteria Collection, Laboratorium voor Microbiologie, University Ghent, Ghent, Belgium) for performing DNA-DNA hybridization analyses, 16S rRNA gene sequence analyses and Biolog analysis. This research was supported by the Government of Spain (CICYT project CTQ 2007-60749/PPQ) and by the Autonomous Government of Catalonia (grant no. 2009SGR1212).

\section{References}

Antranikian, G., Vorgias, C. E. \& Bertoldo, C. (2005). Extreme environments as a resource for microorganisms and novel biocatalysts. Adv Biochem Eng Biotechnol 96, 219-262.

Barrow, G. I. \& Feltham, R. K. A. (editors) (1993). Cowan and Steel's Manual for the Identification of Medical Bacteria, 3rd edn. Cambridge: Cambridge University Press.

Bozal, N., Montes, M. J., Tudela, E., Jiménez, F. \& Guinea, J. (2002). Shewanella frigidimarina and Shewanella livingstonensis sp. nov. isolated from Antarctic coastal areas. Int J Syst Evol Microbiol 52, 195-205. 
Bozal, N., Montes, M. J. \& Mercadé, E. (2007). Pseudomonas guineae sp. nov., a novel psychrotolerant bacterium from an Antarctic environment. Int J Syst Evol Microbiol 57, 2609-2612.

Bozal, N., Montes, M. J., Miñana-Galbis, D., Manresa, A. \& Mercadé, E. (2009). Shewanella vesiculosa sp. nov., a psychrotolerant bacterium isolated from an Antarctic coastal area. Int J Syst Evol Microbiol 59, 336340.

Bruni, V., Gugliandolo, C., Maugeri, T. \& Allegra, A. (1999). Psychrotrophic bacteria from a coastal station in the Ross sea (Terra Nova Bay, Antarctica). New Microbiol 22, 357-363.

Cleenwerck, I., Vandemeulebroecke, K., Janssens, D. \& Swings, J. (2002). Re-examination of the genus Acetobacter, with descriptions of Acetobacter cerevisiae sp. nov. and Acetobacter malorum sp. nov. Int J Syst Evol Microbiol 52, 1551-1558.

De Vos, P., Van Landschoot, A., Segers, P., Tytgat, R., Gillis, M., Bauwens, M., Rossau, R., Goor, M., Pot, B. \& other authors (1989). Genotypic relationships and taxonomic localization of unclassified Pseudomonas and Pseudomonas-like strains by deoxyribonucleic acid : ribosomal ribonucleic acid hybridizations. Int J Syst Bacteriol 39, 35-49.

Ezaki, T., Hashimoto, Y. \& Yabuuchi, E. (1989). Fluorometric deoxyribonucleic acid-deoxyribonucleic acid hybridization in microdilution wells as an alternative to membrane filter hybridization in which radioisotopes are used to determine genetic relatedness among bacterial strains. Int J Syst Bacteriol 39, 224-229.

Goris, J., Suzuki, K., De Vos, P., Nakase, T. \& Kersters, K. (1998). Evaluation of a microplate DNA-DNA hybridization method compared with the initial renaturation method. Can J Microbiol 44, $1148-1153$.

King, E. O., Ward, M. K. \& Raney, D. E. (1954). Two simple media for the demonstration of pyocyanin and fluorescin. J Lab Clin Med 44, 301-307.

Kriss, A. E., Mitskevich, I. N., Rozanova, E. P. \& Osnitskaia, L. K. (1976). [Microbiological studies of the Wanda Lake (Antarctica)]. Mikrobiologiia 45, 1075-1081 (in Russian).

Ma, Y., Wang, L. \& Shao, Z. (2006). Pseudomonas, the dominant polycyclic aromatic hydrocarbon-degrading bacteria isolated from Antarctic soils and the role of large plasmids in horizontal gene transfer. Environ Microbiol 8, 455-465.

Maugeri, T. L., Gugliandolo, C. \& Bruni, V. (1996). Heterotrophic bacteria in the Ross Sea (Terra Nova Bay, Antarctica). New Microbiol 19, 67-76.

Mesbah, M., Premachandran, U. \& Whitman, W. B. (1989). Precise measurement of the $\mathrm{G}+\mathrm{C}$ content of deoxyribonucleic acid by highperformance liquid chromatography. Int J Syst Bacteriol 39, 159-167.

Molin, G., Ternström, A. \& Ursing, J. (1986). Pseudomonas lundensis, a new bacterial species isolated from meat. Int J Syst Bacteriol 36, 339-342.

Montes, M. J., Bozal, N. \& Mercadé, E. (2008). Marinobacter guineae sp. nov., a novel moderately halophilic bacterium from an Antarctic environment. Int J Syst Evol Microbiol 58, 1346-1349.
Mulet, M., Lalucat, J. \& García-Valdés, E. (2010). DNA sequencebased analysis of the Pseudomonas species. Environ Microbiol 12, 1513-1530.

Nevot, M., Deroncele, V., López-Iglesias, C., Bozal, N., Guinea, J. \& Mercade, E. (2006). Ultrastructural analysis of the extracellular matter secreted by the psychrotolerant bacterium Pseudoalteromonas antarctica NF3. Microb Ecol 51, 501-507.

Niemann, S., Pühler, A., Tichy, H. V., Simon, R. \& Selbitschka, W. (1997). Evaluation of the resolving power of three different DNA fingerprinting methods to discriminate among isolates of a natural Rhizobium meliloti population. J Appl Microbiol 82, 477-484.

Reddy, G. S. N., Matsumoto, G. I., Schumann, P., Stackerbrandt, E. \& Shivaji, S. (2004). Psychrophilic pseudomonads from Antarctica: Pseudomonas antarctica sp. nov. and Pseudomonas proteolytica sp. nov. Int J Syst Evol Microbiol 54, 713-719.

Shivaji, S., Rao, N. S., Saisree, L., Sheth, V., Reddy, G. S. N. \& Bhargava, P. M. (1989). Isolation and identification of Pseudomonas spp. from Schirmacher Oasis, Antarctica. Appl Environ Microbiol 55, 767-770.

Tamura, K., Dudley, J., Nei, M. \& Kumar, S. (2007). MEGA4: molecular evolutionary genetics analysis (MEGA) software version 4.0. Mol Biol Evol 24, 1596-1599.

Tindall, B. J. (1990). A comparative study of the lipid composition of Halobacterium saccharovorum from various sources. Syst Appl Microbiol 13, 128-130.

Tindall, B. J., Rosselló-Móra, R., Busse, H.-J., Ludwig, W. \& Kämpfer, P. (2010). Notes on the characterization of prokaryote strains for taxonomic purposes. Int J Syst Evol Microbiol 60, 249-266.

Wayne, L. G., Brennen, D. J., Colwell, R. R., Grimont, P. A. D., Kandler, O., Krichevsky, M. I., Moore, L. H., Moore, W. E. C., Murray, R. G. E. \& other authors (1987). International Committee on Systematic Bacteriology. Report of the ad hoc committee on reconciliation of approaches to bacterial systematics. Int J Syst Bacteriol 37, 463-464.

Wilson, K. (1987). Preparation of genomic DNA from bacteria. In Current Protocols in Molecular Biology, pp. 2.4.1-2.4.5. Edited by F. M. Ausubel, R. Brent, R. E. Kingston, D. D. Moore, J. G. Seidman, J. A. Smith \& K. Struhl. New York: Greene Publishing and WileyInterscience.

Yamamoto, S. \& Harayama, S. (1998). Phylogenetic relationships of Pseudomonas putida strains deduced from the nucleotide sequences of gyrB, rpoD and 16S rRNA genes. Int J Syst Bacteriol 48, 813819.

Yarza, P., Richter, M., Peplies, J., Euzeby, J., Amann, R., Schleifer, K. H., Ludwig, W., Glöckner, F. O. \& Rosselló-Móra, R. (2008). The All-Species Living Tree project: a $16 \mathrm{~S}$ rRNA-based phylogenetic tree of all sequenced type strains. Syst Appl Microbiol 31, 241-250.

Yumoto, I., Kusano, T., Shingyo, T., Nodasaka, Y., Matsuyama, H. \& Okuyama, H. (2001). Assignment of Pseudomonas sp. strain E-3 to Pseudomonas psychrophila sp. nov., a new facultatively psychrophilic bacterium. Extremophiles 5, 343-349. 